\title{
A REGIONAL EXPERIMENT IN PRACTICAL DEVELOPMENT OF INDUSTRIES
}

\author{
WM. LEAVITT StODDARD*
}

In the I920's a group of forward-looking business and professional men in New England undertook to study the economic basis of this 6-state region-the oldest industrialized region in the United States. This research was stimulated by the fact that industrialization was speeding westward and southward, drawing with it manufacturing concerns long rooted in New England. Evidently here was a trend which required diagnosis and perhaps action.

The most interesting conclusions drawn by this group were these:

I. That the New England economy is based primarily on industry, not agriculture.

2. That small and medium-sized industries, not large mass production industries thrive best in New England.

3. That small industry has special problems of finance, management, research, marketing, etc., not adequately met by existing facilities.

4. That a special service organization equipped to assist small industry in solving these problems should be set up to provide, at reasonable costs, the services and facilities found to be needed by small industry.

As a rule several years elapse between the formulation of an idea and putting it into practical use. After what proved to be an abortive start in r929, ten years later several of the original group began the definite planning which resulted in the organization of the New England Industrial Development Corporation. The first published statement began with these carefully worded paragraphs:

"Purpose and Objective: Throughout New England there are many small and intermediate-sized companies in expanding industries whose continued growth and profits are dependent upon their ability to secure long-term or permanent equity financing.

"Existing agencies cannot solve this problem. Commercial banks, investment bankers, investment trusts, and insurance companies cannot by their very nature supply longterm or permanent capital in amounts up to $\$ 100,000$.

"Meeting these needs with capital alone will not always solve the problem. A complete and continuous advisory management service based upon analysis of data relating to operating problems should be supplied as well. Sound management even more than collateral is the strongest security the supplier of capital can have.

-A.B., 1907, M.A., 1908, Harvard College. President, New England Industrial Development Corporation. Director, Aeolian-Skinner Organ Company, Inc.; North Atlantic Packing Company. Member, Board of Governors, Boston City Club; Chairman, Committee on Committee Personnel, Boston Chamber of Commerce; member, Industrial Development Committee, New England Council. 
"The New England Industrial Development Corporation has been formed for the general purpose of assisting established companies, and promising new enterprises, whose requirements are too small to secure underwriting by investment houses, to obtain permanent capital or long-term funds not ordinarily within the sphere of commercial bank accommodations."

The statement emphasized that it would be the policy of the corporation "to make complete and factual studies of each situation believed to be worth complete investigation are prepared for presentation to each member of the board of directors."

Further, the statement declared that the policy of the corporation was to stress management rather than collateral considerations as security for the successful carrying out of its purposes: "By means of continuous analysis of data relating to operating problems, staff advisers are in a position to assist in formulating management policies with the view of improving the earning power of client concerns.

"Charges for the limited advisory or control management services are determined at a figure sufficiently in excess of actual cost to assure maintenance of this function on self-sustaining basis. Unless the need for such services warrants additions to its own staff, and whenever deemed necessary and expedient, the corporation will employ outside and independent management counsel."

The program of the Corporation was outlined as follows:

r. Undertake studies of the essential factors of businesses for special report or survey purposes or as preliminary to recommendations to qualify a business for adoption of a financing program.

2. Act to bring together small business requiring intermediate credit and capital with sources of differing types of capital or credit.

3. Render necessary management services to concerns for which it obtains financial assistance.

4. Assist local interests, such as chambers of commerce, to organize channels through which local industries can be helped to obtain needed working capital and longterm or permanent funds.

The Corporation was organized in Boston, under the statutes of Massachusetts with a board of directors fairly representative of business and professional men of standing, experience and broad interests, particularly in the problems of small industry. In order to supplement the board, an Advisory Committee was created including representatives of public and semi-public bodies, banks, railroads and public utilities. Modest but sufficient financial support was received from several individuals to enable the Corporation to open offices with a small staff. Everyone recognized that the effort was an experiment, not entirely without precedent (the Industrial Corporation of Baltimore in particular), and that time, patience and hard work alone would result in failure or success.

In a recently published report of progress the Corporation has summarized in broad and at the same time specific terms, its accomplishments:

Much of the initial work was related directly to war production-in subcontracting, by serving as a clearing house between government and large industry needs 
and small industry resources; in financing by serving as a clearing house between small war industries and large capital resources; in production and management engineering by serving as a clearing house between small industries and sources of expert assistance.

Hundreds of thousands of dollars of production have been secured and scores of industries assisted, in these fields: surgical instruments; valves; machine shops in war work; welded products; boat construction; woodworking shops; scientific medical apparatus; chemicals and industrial apparatus; machine tools; castingsiron, steel, aluminum, bronze; and others.

Numerous civilian industries helped by the Corporation in finding their place in war production are now relying on the Corporation for aid in reconversion to peacetime production .... in the light of new products, new processes, market changes and other factors to be taken into account in postwar planning.

Industries in the following fields have been established, or are being exploredall capitalizing on the results of New England research and invention: Food products; synthetic leather; furniture; toys; various mechanical devices; therapeutic electric lamp; charcoal kiln; wood distillation stove; steam valves; motor boat accessories; automotive accessory; precision castings; stud gun; wood novelties; detachable rubber heel; pile-splicing device; starch cooker; fireproofing and insulation; plastic materials; electric press; and products from industrial wastes.

As to relocation of industry, contacts have been established and in several instances negotiations begun, to bring industries to New England, to establish branch plants in New England, or to secure work for small New England plants on a subcontract basis from industries in other areas.

Marketing arrangements have been made with local and national selling organizations to handle products of various New England small industries.

New England patented products which cannot compete with other same-use products in distant markets of the country are being offered on a royalty basis to manufacturers in distant regions whose output does not compete in the New England market.

Development research projects to bring feasible but as yet unperfected new products to a stage where they are ready for market production have been undertaken with the assistance of specialists at M. I. T.; Mason Laboratory, Yale University; Harvard University; University of New Hampshire, Engineering Experiment Station; individual industrial chemists, engineers and industrial managers. Active cooperative relations exist with New England Industrial Research Foundation and Engineering Societies of New England, Inc., whose services the Corporation does not duplicate.

The secret of such success as the Corporation has had is due simply and solely to the fact that the Corporation has organized the available knowledge, services and facilities which can be of value in helping to solve the problems of small industry. It is a clearing-house, a clinic, a contact agency, drawing through its own funnel 
the knowledge and experience of scores if not hundreds of individuals and agencies for the benefit of its clients. The chart shown on page 366 portrays this organization.

Because specific cases tell a more eloquent story than an equivalent number of words expended otherwise, the following paragraphs from a service bulletin issued by the Corporation give a vivid picture of the types of cases currently in process of solution:

\#ros Machine shop wants consumer or other item. Facilities of roo man machine shop include screw machines up to $25 \%$ ", grinding and customary secondary operations. Prefer to assemble largely, necessarily limited to machine shop product.

\#xo6 Woodworking plant in Vermont now fully employed on war work wants-postwar products to make of Beech, Birch and Maple. Would prefer item where volume sales can be made to a few large outlets.

\#ro7 Items wanted for cooperative development with inventors through pilot plant stage of any small items requiring precision machining and superior knowledge of production engineering. Gadgets, electrical devices, etc.?

\#108 Welding shop (125 men) wants both present and future work. Especially interested in making metal boxes, cases, tanks, etc. Also interested in making patentable items for itself or others, such as all or part of agricultural items. No job too big or too small in any welded metals.

\#rog Small boat yard (12 men) of craftsmanship nature wants to make small patentable items of wood for itself and others and small boats of plastic on secret or patentable process. This last on royalty or cooperative basis.

\#IIO Large high-grade electronic and optical laboratory (with production shop) will develop and produce meritorious post-war items for itself or others on royalty profit-sharing or other negotiated basis.

\#IrI Small production shop, highly skilled in cost-saving assembly by "silver" soldering (rather than machining) methods offers its shop and/or consulting services on present or future items. Will also produce original items for itself or others on royalty or cooperative basis.

\#II2 Large company with facilities for handling bulk products such as sand, with heavy trucks serving 50-100 mile radius around Boston, seeks sizable activity, program participation, or product preferably a basic material.

$\#_{113}$ Medium-sized Dow Metal and Aluminum Foundry (owning centrally located buildings suitable for industrial sales offices and projects) will buy or operate on negotiated basis small industries not necessarily connected with the foundry, will take over sales agencies or otherwise invest capital, managerial ability and sales-merchandising experience in new or established projects. Young, successful, open-minded owners will consider any worthwhile opportunity.

\#II4 Medium-sized (250 men) welding shop with automatic welding equipment wants to make for itself or others on royalty, cooperative or negotiated basis, steel, aluminum, etc., postwar items of any size. Will go all the way from cooperative development of an "idea" to outright purchase of an established business.

\#IIS Industrialist will invest around $\$ 25,000$ with or without use of his machine shop in worthwhile new project or established business. Unusual promotion and engineering ability used by government agencies is now available with $\$ 25,000$ cash to "put over" any real opportunity. 
\#II6 Machine shop office manager and cost accountant with abilities to set up and operate automatic machines, etc., is "stuck" with a small low-overhead machine shop. Open to any proposition.

\#II7 Efficient I0o man Connecticut woodworking shop (manufacturing rough lumber and plywood into finished wood products) would like to make such items for others on order. Typical items: cabinetwork, store fixtures, wood chucks for metal spinning, etc., or would make a few special items on cooperative basis where sales work is provided for them.

\#II 8 A 75 year old construction company (road, air-port, bridges, buildings, etc.) is willing to back parties with products, ideas or patentable designs in such lines, act as sales-service agents or otherwise cooperate with manufacturers, inventors, individuals or communities.

\#Ixg A small Pre-World-War I machine shop with its own line of automotive and industrial tractor, automotive and hardware tools seeks allied items. Will make such items for others or add to its own line on royalty or cooperative basis.

Again using the case method, the following illustrate how certain specific problems were solved. It should be noted that the solutions in all cases were the result of careful analysis of the factors in the situation and of then bringing into play knowledge and services-readily available-to cooperate with the management.

Here are typical instances:

\section{Case No. 47: Seafood}

In I94I, two young men with a capital of $\$ 75^{\circ}$ found their orders for canned seafood greater than they could supply. They consulted the Corporation. Their situation was analyzed. Government and other agencies provided seafood industry data which disclosed non-seasonal and interesting profit possibilities. Initial private capital was obtained to provide plant and equipment. As volume and profit increased, additional private capital and banking arrangements were negotiated. Today, under continued Corporation guidance, this new industry employs 75 to roo persons in a town which needed an industry. It seasonally borrows and repays $\$ 50,000$ to $\$ 75,000$ from banks. Annual sales now exceed $\$ 150,000$. The two young men still hold control of the business.

The money referred to above was obtained from private sources. 'The company sold preferred stock to 6 or 8 investors who received in addition a bonus of $20 \%$ of common stock of the company. The preferred stockholders were given representation on the Board of Directors and the right to control the company in case dividends on the preferred failed under certain conditions. The unusual feature of this arrangement is that theoretically the company was worth considerably less than the amount of capital thus provided, but those providing the capital believed that it would be better for them and for the company for majority ownership and responsibility to remain in the original owner under reasonable supervision. The purposes for which the capital was raised included permanent equipment and could not be covered by bank loans under existing laws and customs.

\section{Case No. 75: New Company}

When the war started, a foreman who had worked in a large company started his own business in a typical garage set-up. He had unusual abilities in production and design but lacked business experience. A friend introduced him to the Development Corporation. Arrangements were made to assist him in setting up his books, organizing his paper work 


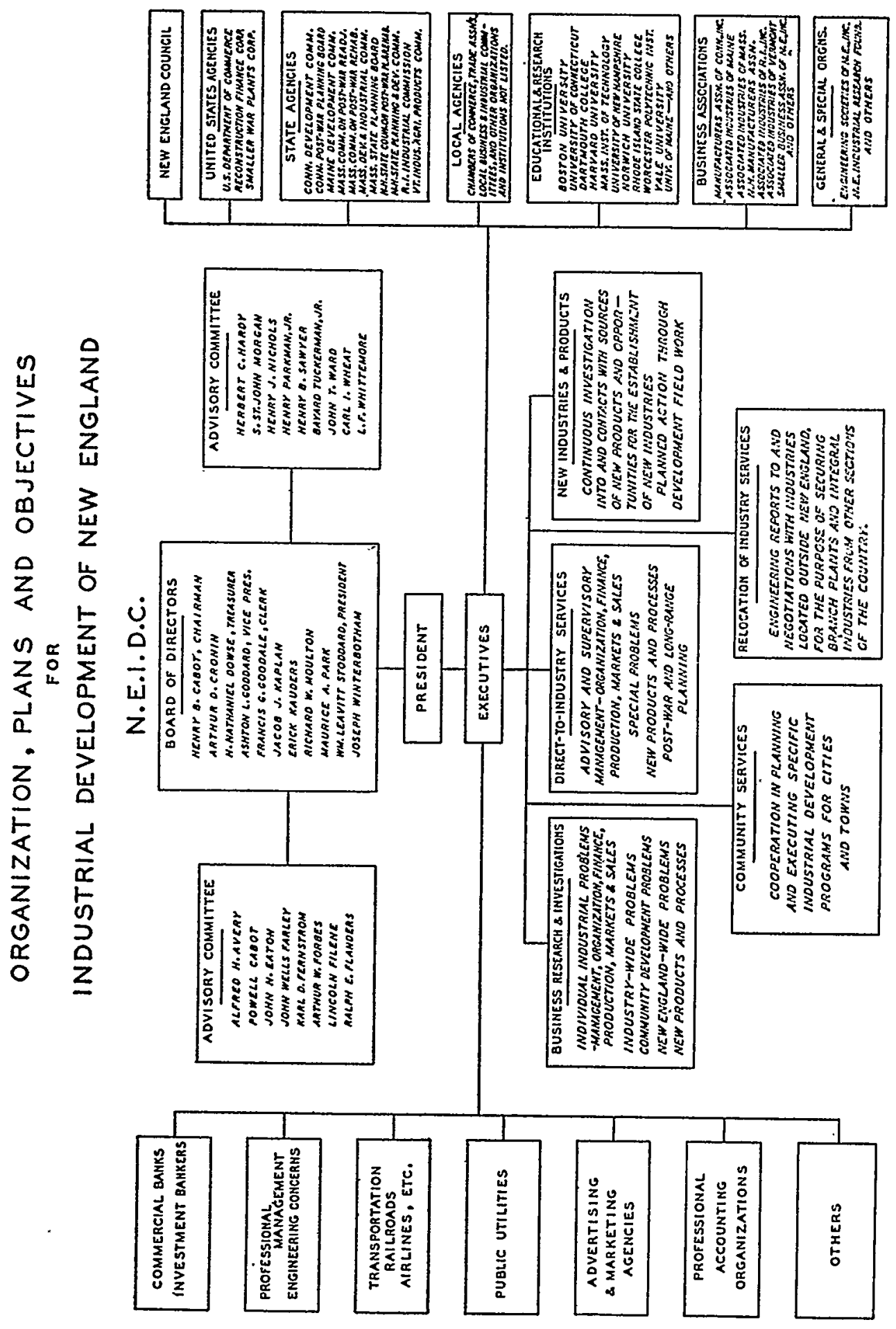


and financing, and eventually incorporating. The Development Corporation also helped him to secure work and apply his production management abilities to the aid of other small companies.

\section{Case No. 120: Surgical Instruments}

In trying to change from a craftsman shop to straight-line production, a roo-year-old surgical instrument manufacturing company got into serious difficulties. Chronically, it had no money to meet its payroll and owed $\$ 25,000$ more than its assets. Government loans and taxes were seriously in default. The company had lost money steadily for two years.

Because bankruptcy would have stopped production of urgently needed war items (surgical instruments, precision parts for bombs, etc.) and because of its obligation to assist New England industry, Development Corporation offered to lend a staff consultant on a part-time basis.

The company was brought to a profit position. A large percentage of the outstanding creditors agreed to accept time payments. Substantial payments were made on delinquent taxes and government loans. Production costs were lowered by proper engineering; production was increased $300 \%$. Fiscal and administrative management was improved. Creditors, customers, government agencies and other agencies and individuals put their shoulder to the wheel to turn the tide for this New England industry.

As a direct by product of this effort, several creditors doing subcontract work for this industry were also saved from serious difficulties. Several of these independent industries are now calling upon Development Corporation for help in solving some of their own problems.

\section{Case No. 29: Machine Shop}

Anticipating war time curtailment of its usual production and for patriotic reasons, a medium-sized New England company expanded its machine shop facilities. Lacking experience and contacts in its new operations, many difficulties arose. Development Corporation has assisted in establishing good contacts to assure steady flow of the right kind of war orders, in locating adequate shop supervisors, in attaining efficient production and currently in development of several new "post-war" projects to use facilities when war contracts are cancelled.

After its third year of experimental operation, the Corporation reviewed what had been learned and charted its functions in order to promote their more orderly development. The accompanying chart is the result.

The form of the chart pictures the essential service of the Corporation-that of a coordinating action agency. Its relatively small staff is supplemented and supported by the directors-all experienced business or professional men; and by the Advisory Committee, similarly equipped to aid. Thus the staff is increased to some 30 men and is of a character which, if employed on a commercial basis, would be beyond the means of any but the largest corporation. In the footnote to this page is a descriptive list of these two groups, showing their many connections. ${ }^{1}$

\footnotetext{
${ }^{1}$ New England Industrial Development Corporation: Board of Directors

Henry B. Cabot, Chairman of the Board, N. E. Industrial Development Corp. Director: State Street Trust Co. : Samuel Cabot, Inc. Member of Corporation, Peter Bent Brigham Hospital.
} 
Arthur D. Cronin, Partner, Kaler, Carney, Liffer \& Co. Director: Insurance Brokers Assoc.; Boston Executives Assoc.

H. Nathaniel Dowse, Treasurer and Director, N. E. Industrial Development Corp. Clerk, Dennison Manufacturing Co.

Ashton L. Goddard, Vice President and Asst. Treas., N. E. Industrial Development Corp. Manager, N. E. Mercantile Claims Division of Dun \& Bradstreet, Inc.

Francis G. Goodale, Clerk of Corporation, N. E. Industrial Development Corp. Member of the firm of Hill, Barlow, Goodale and Wiswall. Director: Aeolian-Skinner Organ Co., Inc.; Frost Coal Co.; Trustee, New England Fund.

Jacob J. Kaplan, Member of the firm of Nutter, McLennen \& Fish. Director: Arnold Glove Grip Boot Shops, Inc.; Beth Israel Hospital; Boston Municipal Research Bureau; Eastern Mass. Street Railway Co.; Federated Department Stores, Inc; U. S. Trust Co.

Erick Kauders, Partner and General Manager, Craig Machine Co.

Richard W. Moulton, Fáctory Manager and Director, N. E. Confectionery Co. Director: Lovell \& Covel Co.

Maurice A. Park, Vice President and Director, The Marvellum Co., Holyoke.

Wm. Leavitt Stoddard, President, N. E. Industrial Development Corp. Vice President, Lincoln and Therese Filene Foundation, Inc. Director: North Atlantic Packing Co.; Acolian-Skinner Organ Co., Inc.

Joseph Winterbotham (Vermont), Chairman, Vermont Industrial Agricultural Products Commission. Director: Pennoyer Merchants Co.; Pennoyer Commission Co.; T. H. Winterbotham \& Sons-all of Chicago.

\section{Advisory Committee}

Alfred H. Avery, President, North American Chemical Co. Trustee, Boston University.

Powell Cabot, Chairman, Mass. Development \& Industrial Commission. Director, U. S. Employment Service in Massachusetts.

John N. Eaton, Vice President, Merchants National Bank of Boston.

John Wells Farley, Member of the firm of Herrick, Smith, Donald, Farley \& Ketchum; Director: American Airlines, Inc.; State Street Trust Co.; Merrimac Hat Corp.; Nashua Mfg. Co. Member of Board of Overseers, Harvard College.

Karl D. Fernstrom, Professor of Business Management, Department of Business \& Engincering Administration, Mass. Institute of Technology. Vice President, North Carolina Shipbuilding Co. Co.).

Arthur W. Forbes, Manager, J. C. Rhodes \& Co., New Bedford (Subsidiary of U. S. Shoe Machinery

Lincoln Filene, President and Director, Wm. Filene's Sons Co. Director: Bloomingdale Bros.

Ralph E. Flanders, President, Federal Reserve Bank of Boston.

Herbert C. Hardy, Vice President, Mechanics National Bank, Worcester.

S. St. John Morgan, Vice President and Director, State Street Trust Co. Director: Nashua Mfg. Co.; Bigelow \& Dowse Co.; H. and B. American Machine Co.; Merrimac Hat Corp.; Pelzer Mfg. Co.

Henry J. Nichols, President, Boston Chamber of Commerce. Vice President and Director, National Shawmut Bank of Boston. Director: Caribbean Sugar Co.; Dorchester Mutual Fire Insurance Co.; Mass. Div., N. E. Council; Powdrell \& Alexander, Inc.

Henry Parkman, Jr. In the Service of the United States.

Henry B. Sawyer, Trustee: N. Y., N. H. \& Hartford Railroad Co., Suffolk Savings Bank for Seamen and Others. Vice President, Boston Symphony Orchestra, Inc. Member Advisory Board, Mass. Investors' Trust.

Bayard Tuckerman, Ir., Member of the firm of OBrion, Russell \& Co. Director: A. \& J. Caldwell Co.; Boston Garden-Arena Corp.; National Rockland Bank of Boston; Ritz-Carlton Hotel Co. of Boston. Member, State Racing Commission.

John T. Ward, Vice President (Technical Research and Power Sales) Boston Edison Co.

Carl I. Wheat, Attoracy-at-law, Washington, D. C.

L. F. Whittemore, Assistant to the President, B. \& M. Railroad, Maine Central RR. Director: Brown Co.; First National Bank of Concord, N. H.; Northeast Airlines, Inc. 
The small permanent staff together with the directors and advisors form the permanent "brains" of the corporation. But this is not enough. On the right and left sides of the chart are listed both types of organization and specific agencies which can and do contribute to the analysis and solution of problems. It requires little imagination to realize the vast storehouse of knowledge which can be brought to a focus on the problems of an individual small industry through the utilization of such services.

The services of the Corporation itself are shown in the five boxes in the lower center part of the chart. They are self-explanatory.

The N. E. I. D. C. has frequently been considered a research organization. In a sense this is true, because it uses research constantly. But industrial research is of two kinds. One is technical research-chemical, physical, electrical, engineering, etc. This kind of research discovers new products and processes, new materials and techniques. The second is business or development research. Its object is to create businesses on the basis of the things discovered by technical research.

A new device lying on the scientist's table in the laboratory is of no use to the world till business research has been applied and an industry has been developed to exploit the commercial opportunities latent in the device.

The industrial growth of an area such as New England requires that these two types of research be joined into a program of deliberate exploration for new industries. There is nothing novel about this. Many an existing industry is the result of this process. But till lately there has been no organized effort by the community to plan and carry out a program creating new industries.

Today in the Pacific Northwest, such a program has been established. The empire builders of that area are planning a regional industrial future based on cheap electric power, threatening the industrial east with a competition never heretofore dreamed possible. The announced plan contemplates industries in these specific fields each carefully studied: Food; textile and fibre; apparel; furniture; paper; printing; chemicals; petroleum products; coal products; rubber; leather; stone, clay and glass; iron and steel; non-ferrous; electrical machinery; automobiles and equipment, miscellaneous.

A central force in this amazing program is the Bonneville Power Administration, a division of the U.S. Department of the Interior. This public agency, supported by revenues derived from the sale of public power, works closely with the Northwest States Development Association, a body similar in purpose to the New England Industrial Development Corporation. A study entitled, "Pacific Northwest Opportunities," states that "the chief aim is to indicate a pattern of development so as to create a stronger and better balanced economy for the region, a more reasonable economy that will eliminate waste of resources, and improve efficiency of resource utilization, add to wealth and raise living standards."

A plan similar in purpose for New England is beginning to emerge. Here is the oldest industrial region in the nation, a region still rich in natural resources- 
those of the sea, of the forest and to some extent of the soil. Not as rich as the Pacific Northwest but richer in population, and in skills both of labor and management, than perhaps all other sections of the country. "Know-how," another name for Yankee ingenuity, gives the world all kinds of gadgets, machines, machine tools and finely made industrial and consumer products. It will take the Pacific Northwest at least a generation or two to equal New England in these respects. This is not the writer's personal opinion. It is that of a development executive of that region.

All this is of considerable interest to large companies considering decentralization as part of their postwar program. A free special confidential information service is provided to such companies.

The development corporation idea has been slow in growth. The pioneer company, the Baltimore Industrial Corporation, stood alone for many years. In various communities development groups started-and stopped-frequently organized as local "boosters," or to provide capital for new industries. Few have deliberately sought to organize the resources of the community on a long-time basis in accordance with the program visualized by our Corporation. But in recent months, to judge by the inquiries received in our offices, the idea has caught on and leaders in many parts of the country are studying it. The Smaller War Plants Corporation, following an extensive field study which included the N. E. I. D. C. has adopted a policy of cooperation with such groups wherever they exist and of encouragement of the formation of new development groups where local conditions warrant and leadership exists.

In the new industrial era which the country is now entering, our structure may well be sounder and more enduring as the result of this new type of practical integration of industry with the resources of the local or regional communities whose economic welfare depends on constantly growing industry. 